\title{
Analyzing Energy Security and Sustainable Development in Southeast Europe from a Multidimensional Approach
}

\author{
Fatri Morina, PhDc \\ Assistant Professor / European University of Tirana \\ fmorina@uet.edu.al
}

\begin{abstract}
Energy plays a vital role in the sustainable development of a nation and regions as well, thus affordable and reliable energy supplies are crucial for this development. South East Europe countries are characterized from high energy dependence and face several difficulties in guaranteeing a sustainable development. Only an integrated approach, which combines all the dimensions of energy security, can be a successful way for nations to guarantee their energy security and sustainable development. The scope of this paper is to analyze energy sector and sustainable development in Southeast Europe, with a focus on economic, social, environmental and geopolitical dimension of energy security. The methodology used for this paper combines energy security approach and Regional Security Complex Theory, with a focus in Regional Energy Security Complexes. Energy sector in this region is characterized by a problematic energy infrastructure, low system reliability and low efficiency, energy dependence and lack of diversification of energy sources, all elements with a direct impact on energy security. The data used for this paper are based upon the data of World Bank, International Energy Agency, International Monetary Fund and United Nations.
\end{abstract}

Keywords: Energy Security, Sustainable development, Southeast Europe

\section{Introduction}

Sustainable development and energy security are two of the most important topics nowadays. Many efforts are being put to develop a society which ensures harmony between environment, society and economic growth. In this aspect, energy plays a vital role in the sustainable development of a nation and regions as well, thus affordable and reliable energy supplies are crucial for this development. South East Europe countries are characterized from high energy dependence and face several difficulties in guaranteeing a sustainable development. The linkage between energy security and sustainable development is a matter of great importance, thus the scope of this paper is to analyze energy security and sustainable development in Southeast Europe from a multidimensional approach. This paper focuses in the SEE6 countries, which includes Albania, Bosnia and Herzegovina, Kosovo, F.Y.R Macedonia, Montenegro and Serbia. This area is composed from states that have different problems and opportunities as well, but energy security and sustainable development are two key issues with a direct impact on every state in particular as well as the entire region in general. As mentioned in the South East Europe Transnational Cooperation Program, "The South-East Europe area is the most diverse, heterogeneous and complex transnational cooperation area in Europe, made up of a broad mix of countries. The emergence of new countries and with it the establishment of new frontiers has changed the patterns of political, economic, social and cultural relationships".

In this situation, the paper raises some questions: Which is the energy security situation in SEE6 countries? What are some of the problems faced by these countries in terms of sustainable development? What measures and policies must be taken to ensure energy security and sustainable development in SEE6 countries? Before answering these questions, is necessary to explain the key concepts of the paper, energy security and sustainable development, and the used methodology. These issues will be elaborated in the next section of the paper.

\section{Literature Review and Work Methodology}

The literature review process showed that despite previous works focused on energy security and sustainable development, there is no a general consensus for the definition of the terms. Definitions of 'energy security' range from narrow issues of physical supply disruption to broader ones involving the economic, environmental, and political consequences of changes 
to energy markets (Dreyer \& Stang, 2013: 1). This is due to the positions and interests of each actor. The International Energy Agency refers to energy security as "the uninterrupted availability of energy sources at an affordable price" (IEA, 2011). Scheepers (2006) and Kirchner (2007), share the idea that secure energy means that the risks of interruption to energy supply are low. Daniel Yergin (2011) argues that "Energy security also means the ability to access resources and develop them, ensuring sufficient investment for future supplies, and establishing the governmental-private sector arrangements to respond to crises and ensure international cooperation". Regarding the definition of sustainable development, the most frequently quoted definition is: "Sustainable development is development that meets the needs of the present without compromising the ability of future generations to meet their own needs. It contains within it two key concepts:

- $\quad$ The concept of needs, in particular the essential needs of the world's poor, to which overriding priority should be given; and

- The idea of limitations imposed by the state of technology and social organization on the environment's ability to meet present and future needs." (WECD, 1987: 43).

Another way to define of sustainable development is the one of U.S. National Research Council (1999), shown in the figure below.

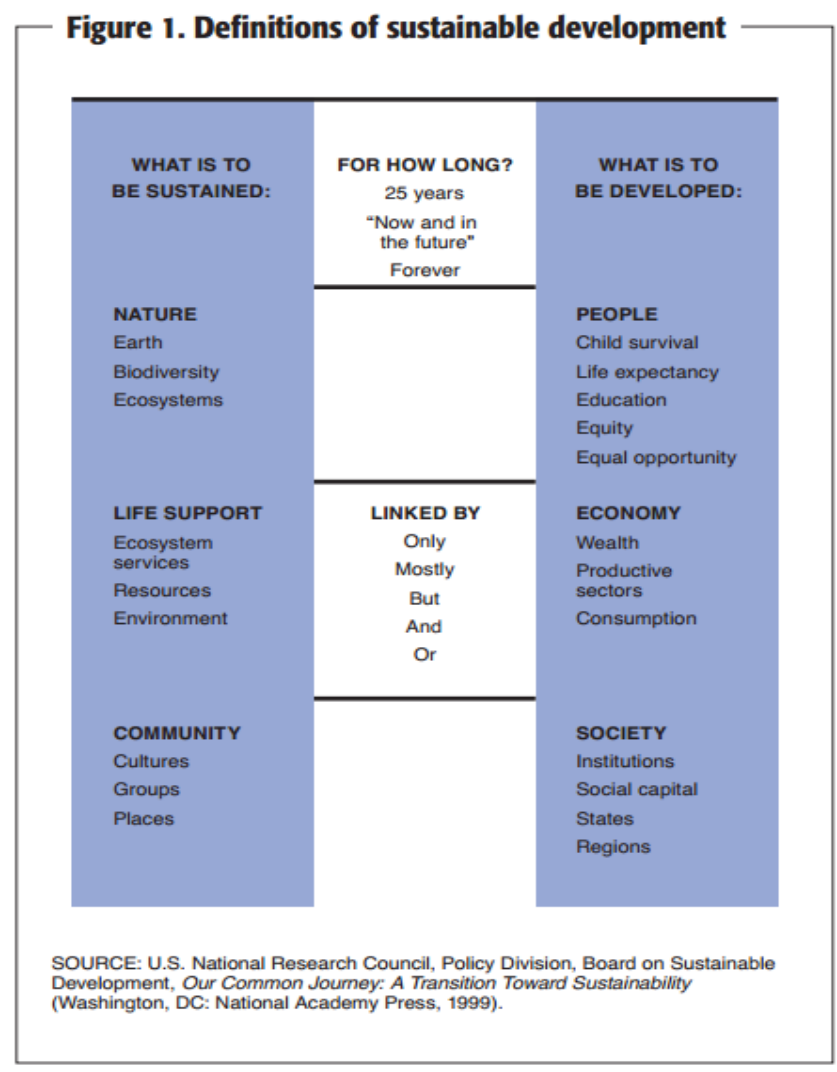

The methodology used in this paper combines energy security approach and Regional Security Complex Theory, with a focus in Regional Energy Security Complexes. Regional Security Complex Theory suggests "an analytical scheme for structuring analysis of how security concerns tie together in a regional formation...it's a set of units whose major processes of securitization, de-securitization or both are so interlinked that their security problems cannot reasonably be analyzed or 
resolved apart from one another" (Waever, 2004). In a region where the constituent states share closely interdependent security conditions and understandings of energy, Regional Energy Security Complexes are formed (Sharples, 2012).

\section{Analysis of the findings}

Table 1: Economic and energetic indicators of SEE6 countries (2012)

\begin{tabular}{|l|l|l|l|l|l|l|l|}
\hline $\begin{array}{l}\text { SEE6 } \\
\text { Countries }\end{array}$ & $\begin{array}{l}\text { Population } \\
\text { (in million) }\end{array}$ & $\begin{array}{l}\text { GDP (in } \\
\text { billion } \\
\text { USD, } \\
2005)\end{array}$ & $\begin{array}{l}\text { Energy } \\
\text { Production } \\
\text { (in Mtoe) }\end{array}$ & $\begin{array}{l}\text { Energy } \\
\text { Consummation }\end{array}$ & $\begin{array}{l}\text { Energy } \\
\text { Dependence } \\
\text { (\%) }\end{array}$ & $\begin{array}{l}\text { Human } \\
\text { Development } \\
\text { Index (HDI) } \\
\text { Rank/Value }\end{array}$ & $\begin{array}{l}\text { Human } \\
\text { Sustainable } \\
\text { Development } \\
\text { Rankindex } \\
\text { (HSDI) }\end{array}$ \\
\hline Albania & 3.16 & 11.22 & 1.49 & 1.93 & 36.8 & $64 / 0.719$ & $52 / 0.776$ \\
\hline $\begin{array}{l}\text { Bosnia \& } \\
\text { Herzegovina }\end{array}$ & 3.83 & 12.88 & 4.62 & 3.34 & 48.8 & $68 / 0.71$ & $64 / 0.75$ \\
\hline Kosovo & 1.81 & 5.13 & 1.8 & 1.32 & 40.2 & n/a & $\mathrm{n} / \mathrm{a}$ \\
\hline $\begin{array}{l}\text { FYR } \\
\text { Macedonia }\end{array}$ & 2.2 & 7.32 & 1.78 & 1.97 & 72.6 & $71 / 0.701$ & $65 / 0.749$ \\
\hline Montenegro & 0.62 & 2.88 & 0.79 & 0.82 & 48.8 & $49 / 0.769$ & $\mathrm{n} / \mathrm{a}$ \\
\hline Serbia & 7.22 & 27.85 & 11.17 & 9.78 & 49.8 & $60 / 0.735$ & $\mathrm{n} / \mathrm{a}$ \\
\hline
\end{tabular}

Source: World Bank (www.worldbank.org) \& IEA (www.iea.org)

The data of Economic and Energetic indicators of SEE6 countries demonstrates the differences between countries. Serbia has the largest population (7.22 million) and Montenegro has the smallest one (0.62 million). The same situation is even regarding the GDP data. Serbia is the largest producer of energy in the SEE6, an energy production estimated in 11.17 Mtoe, followed by Bosnia \& Herzegovina (4.62 Mtoe). Montenegro produces 0.79 Mtoe and Albania, 1.49 Mtoe. Serbia and Bosnia \& Herzegovina are the top consumers of energy in SEE6 countries, meanwhile Montenegro and Kosovo consume only 0.82 and 1.32 Mtoe. Regarding energy dependence indicator, FYR Macedonia is estimated to have the highest level of dependence, with a value of $72.6 \%$ and Albania has the lowest, with a value of $36.8 \%$. The data shows the need for immediate reforms and the need for the intensification of collaboration between SEE6 countries. This is the only way for these countries to guarantee their energy security and sustainable development. Regarding the Human Development Index, SEE6 countries shares different positions. In a better position are countries like Montenegro (49) and Serbia (60). FYR Macedonia and Bosnia \& Herzegovina ranks in $71^{\text {th }}$ and $68^{\text {th }}$ position. There are no data available for Kosovo. Regarding Human Sustainable Development index, Albania is ranked in $52^{\text {th }}$ position, with an estimated value of 0.776 ; Bosnia \& Herzegovina is ranked in $64^{\text {th }}$ position and an estimated value of 0.75 ; and FYR Macedonia is ranked in the $65^{\text {th }}$ position with an estimated value of 0.749 . This data shows that SEE6 countries have a lot to do regarding Human Sustainable Development. There is no data on HSDI for the other SEE6 countries like Kosovo, Montenegro and Serbia.

Sustainable development and energy security in SEE6 countries is challenged from:

- Degradation of water resources - vital for development and energy production; 
- High levels of air pollution;

- Underdevelopment of infrastructure;

- Natural and human threats to biodiversity;

- High energy dependence from imports;

- Low rates of diversification of energy sources;

- Lack of regional and global collaboration.

\section{Conclusions}

South East Europe countries are characterized from high energy dependence and face several difficulties in guaranteeing a sustainable development. These difficulties vary from air and water pollution and degradation to high energy dependence, lack of diversification and regional collaboration. In order to enchase energy security and sustainable development, SEE6 countries have to increase the level of regional and global collaboration. Countries, state and non-states actors must develop short and long term strategies in order to achieve two of the most important goals; energy security and sustainable development.

\section{References}

[1] Dreyer, I., \& Stang, G. (2013). What energy security for the EU. European Institute for Security Studies, Brief Issue, 39, November.

[2] International Energy Agency (www.iea.org)

[3] International Energy Agency Home Page (www.iea.org).

[4] Scheepers, M.J.J., A.J. Seebregts, J.J. de Jong, J.M. Maters (2006): EU Standards for Energy Security of Supply, ECN-C-06-039, ECN/CIEP, Petten/The Hague, the Netherlands, June 2006. Available at: http://www.ecn.nl/docs/library/report/2006/c06039.pdf

[5] Sharples, J. (2012). Russo-Polish Energy Security Relations: A Case of Threating Dependency, Supply Guarantee, or Regional Energy Security Dynamics? Political Perspectives 6.

[6] South East Europe Transnational Cooperation Program (http://www.southeast-europe.net/)

[7] Waever, O. (2004). Aberystwyth, Paris, Copenhagen - New Schools in Security Theory and their origins between core and periphery. International Studies Association, Paper Series.

[8] World Bank (www.worldbank.org)

[9] World Commission on Environment and Development (WCED). (1987). Our common future. Oxford: Oxford University Press.

[10] Yergin, D. (2011). Energy Security in an Age of Shifting Geopolitical Balance. Available at: http://danielyergin.com/energy-security/. 